\title{
ASKETISME DALAM AJARAN YOGA
}

\author{
Oleh : \\ I Wayan Nerta \\ Dosen Fakultas Brahma Widya IHDN Denpasar
}

\begin{abstract}
Acceleration of science and technology enhances the positive sides of men's life. However, as the social problems remain, peace is just needed. The Hindu Yoga can help people to experience spiritual freedom therefore gain peaceful life. It teaches discipline and strength to the mind, body, and soul.
\end{abstract}

Key Words: Ascetism and Yoga

\section{PENDAHULUAN}

Derasnya era globalisasi dewasa ini yang dimotori oleh kemajuan ilmu pengetahuan dan teknologi serta arus informasi yang nyaris tanpa batas, tidak saja memberikan dampak secara positif bagi kehidupan manusia. Diakui maupun tidak perkembangan tersebut tidak bersamaan seiring dan sejalan dengan kehidupan manusia yang disebut sebagai mahluk ciptaan Tuhan yang paling beradab. Sajian fakta lewat media tidak susah untuk mendapatkan berita dan informasi, prilaku manusia yang mengalami krisis ketauladanan, moral dan etika. Akibatnya manusia dihadapkan pada berbagai dilema dan permasalahan dalam kehidupannya. Kondisi ini membawa manusia dalam hidupnya merasa tidak nyaman, tidak tenang, stress, depresi, dan lain sebagainya.

Sikap persaiangan individu secara berlebihan menjadi ancaman dalam kehidupan sosial bermasyarakat. Sikap gotong royong dalam tanda kutif semakin terdesak pada prinsif-prinsif ekonomi. Fenomena ini menjadikan kehidupan manusia yang cendrung terlalu berlebihan mencintai dirinya sendiri. Akibatnya timbul beberapa keadaan seperti berupaya mengejar kekayaan serta harta benda duniawi. Prilaku tersebut kerap kali dilakukan meskipun melanggar ajaran agama dan kaidah sosial. Sikap yang terlalu memanjakan anak dan istri yang berlebihan, disertai dengan mencintai perhiasan yang mahal dan pakaian yang indah dan megah, dan terlalu berambisi mencari kedudukan yang tinggi yang akhirnya membawa kecintaan yang sangat pada dunia dan ingin hidup kekal abadi . Sikap ini menuju pada sikap yang disebut Abhinavesa (Yoga Sutra Patanjali, II.3) yaitu ketakutan berlebihan pada kematian, keterikatan yang kuat pada kehidupan "rendah", yang menimbulkan ketakutan yang amat sangat pada kematian. Abhinavesa menunjukkan hasrat untuk memiliki yang terbatas pada kehidupan di dunia ini, sifatnya sebagai ikatan pada hal-hal kehidupan dan ketakutan yang kuat untuk mati karena akan kehilangan segala milik duniawi.

Bila dicermati zaman globalisasi yang dimotori oleh kemajuan ilmu pengetahuan dan teknologi dilatarbelakangi oleh filsafat hedonisme yang berorientasi mencari kekayaan, kekuasaan, dan kenikmatan materi maka agama hanyalah menjadi lifeservice belaka dan kehancuran etika, moral dan spiritual akan semakin besar. Perkembangan peradaban dewasa ini yang ditenggarai memberikan kemudahan pada manusia, telah menyibukan manusia itu sendiri. Waktu untuk merenungkan kebesaran Tuhan menjadi 
termarjinalkan. Setiap keberhasilan yang dicapai dianggap sebagai keberhasilan pribadi sehingga ego atau rasa keakuan menjadi-jadi (Cudamani, 1998:3).

Dalam kenyatannya berbagai krisis yang terjadi baik itu krisis politik, krisis ekonomi, maupun krisis moral itu sendiri telah mengakibatkan adanya grafik peningkatan untuk memenuhi kebutuhan hidup manusia sebagai point utama yang harus dikedepankan dan diperjuangkan. Timbulnya persaingan kerja yang muncul kepermukaan tidak jarang digerakkan oleh sifat-sifat serakah dan keinginan yang tak pernah terpuaskan, rasa solidaritas pada sesama semakin berkurang sehingga manusia terkadang dapat dengan mudah mengorbankan sesamanya demi memperoleh kemajuan materi. Akibatnya timbullah berbagai tindakan kriminal, seperti: penipuan, kekerasan, korupsi dan lain sebagainya. Bagi yang gagal mengatasi keadaan zaman tidak sedikit yang frustasi, stress dan mudah terserang berbagai penyakit. Hal ini mencerminkan belum dipahaminya ajaran agama secara baik.

Di sisi lain antara carut marut perang kehidupan, manusia pada hakekatnya masih sangat membutuhkan kedamaian maupun ketenangan sang jiwa. Rasa lelah setelah berhadapan dengan masalah pekerjaan, keluarga, atau sekitarnya, sesungguhnya adalah sebuah isyarat menuntut manusia untuk sejenak mengistirahatkan tubuh dan pikirannya. Keadaan seperti ini membuat manusia cepat lelah, baik secara fisik maupun mental.

Gaya hidup yang modern sekarang ini ditengarai terdapat kecendrungan menonjolkan tekanan mental, kekhawatiran dan tampaknya permasalahan yang tak terpecahkan pada kebanyakan tingkatan, seperti hubungan pribadi, ekonomi dan bahkan ancaman geopolitik perang dan kebinasaan. Cudamani (1999) Akselarasi evolosi ilmu pengetahuan dan teknologi , terutama di bagian kedua abad ini menimbulkan berbagai gejala stress dan strain. Pada saat yang sama pekerjaan yang santai dan setengah santai, semakin meningkat dari hari ke hari seiring dengan kemajuan teknologi dan pemakaian alat-alat kerja yang semakin canggih. Hal ini membuat situasi mental dan fisik kita semakin mudah terserang penyakit. Tanpa suatu pencegahan, tampaknya harapan akan kedamaian rohani semakin menipis (Saraswati, 2002:2).

Berawal dari hal inilah penerapan ajaran agama yang baik dan benar kepada setiap individu merupakan satu-satunya jalan untuk mengurangi munculnya permasalahan ini. Kehidupan yang didasarkan hanya mengejar keterikatan terhadap hal-hal yang bersifat duniawi semata-mata hanya membuat kesengsaraan hidup baik lahir maupun bathin. Keinginan memang energi kemajuan, tetapi tanpa pengendalian diri ia berubah menjadi keserakahan yang membuat kesejahteraan menjadi tidak mungkin tercapai ( Gede Prama, 2013 :115). Untuk meredam berbagai dampak buruk dari kemajuan zaman sekarang ini dan berbagai persoalan hidup yang semakin kompleks adalah dengan membangun kesadaran dan kebijaksanaan melalui pemahaman, pendalaman dan pelaksanaan ajaran agama yang bersumber dari kitab suci.

\section{PEMBAHASAN}

Dalam ajaran agama Hindu memiliki potensi yang cukup tinggi dalam mencapai kedamaian dan ketentraman bathin, karena mampu menawarkan pembebasan spiritual salah satu dengan secara asketis seperti mempraktekkan ajaran yoga. Ajaran ini mengajak manusia untuk lebih memahami dan mengenal dirinya sendiri, dan akhirnya mengenal Tuhannya.

Kata asketisme berasal dari kata benda Yunani askhsi $\mathrm{V}$ yang berarti latihan atau praktik. Kata ini biasanya dikenakan kepada para atlet yang berlatih secara sistematis untuk mendapatkan tubuh yang sehat dan siap untuk bertanding. Selanjutnya, kata ini mulai dinilai 
secara filosofis, rohani, dan etis: latihan bukan hanya untuk fisik, tetapi juga untuk melatih kehendak, pikiran, dan jiwa untuk mencapai kehidupan rohani yang lebih tinggi. Kaum asketik mengambil bentuk penjaminanpenjaminan kondisi anugerah yang dapat terus diperbaharui berbasis kesadaran, bahwa kepemilikan keselamatan religius yang utamanya memberi dia kekuatan untuk bertindak, dan kesadarannya bahwa lewat tindakan-tindakannya, ia melayani Tuhan (Max Weber,2012:398 ).

Sedangkan menurut F.D. Wellem, dalam Viani Leave (2013) istilah asketisme pada mulanya dipakai di dalam filsafat Stoa untuk menunjukkan praktik-praktik memerangi kejahatan dan usaha mengejar keadilan. Pada zaman Gereja Lama, asketisme tampak dalam praktik persiapan seorang Kristen menghadapi kemartiran dan perselibatan. Clemens dan Origenes dari Aleksandria adalah bapa- bapa gereja pertama yang memberi kerangka teoritis terhadap asketisme. Cita- cita asketisme inilah yang menyebabkan lahirnya kehidupan monastik pada abad ke-4, setelah kekristenan diterima dan diakui oleh negara.

Lebih lanjut James Robinson mengatakan bahwa asketisme tidak dapat dikaitkan hanya dengan monastisisme, karena asketisme jauh lebih kompleks daripada monastisisme. Douglas Burton-Christie menjelaskan bahwa asketisme adalah cara umum orang Kristen awal mengekspresikan kesalehan iman mereka, sedangkan monastisisme adalah salah satu bentuk pengembangan asketisme. Jadi, dari penjelasan ini, kita dapat membedakan istilah asketisme dari monastisisme. Asketisme adalah ajaran tentang latihan-latihan penyangkalan diri untuk mendapatkan kemampuan dalam pengendalian diri (Viani Leave, 2013).

Prof. DR. HM. Amin Abdullah (2011) dalam sebuah tulisannya tentang Idul Fitri dan Asketisme Sosial memberikan ulasan sebuah perayaan hari keagamaan yaitu Secara asketis Idul Fitri sering disebut sebagai momen penyucian diri kembali pada sifat fitri setiap manusia. Hari besar yang bermakna perayaan kemenangan dari ritual olah batin dan fisik sebagai laku asketis selama sebulan penuh menjalankan ibadah puasa.

Lebih jauh ulasannya, secara subtil Idul Fitri mampu mendorong pejabat membuka hati dan pintu rumahnya untuk saling memberi maaf kepada sesama dan kaum papa, dan kini menjadi tren silaturahim massal. Sedangkan dalam kebudayaan kontemporer, Idul Fitri menjadi ajang munculnya berbagai kebudayaan populer melalui penampakan tren busana yang selalu berganti setiap Lebaran atau hadirnya berbagai ragam musik dan jenis hiburan religius. Pendek kata, Idul Fitri bukan saja sarat makna asketistik-spiritualistik yang bersifat transenden, tetapi benar-benar tumpah dalam bentangan luas fenomena sosial.

Gede Prama (2010) dalam Lentera Nusa Bali mengatakan, dalam bahasa seorang guru, menggali ke dalam seperti menggali sumur. Awalnya berjumpa rumput, akar, lumpur, batu (baca: halangan, cercaan, penderitaan). Namun, dengan ketekunan, suatu hari akan berjumpa kejernihan kedamaian. Di Bali ia disebut Tapa Yadnya. Sebentuk Yadnya yang dilakukan dengan menggali ke dalam diri. Di Hindu ia diberi sebutan tapa brata yoga samadhi. Di Budha ia melewati tiga langkah sila, samadhi, panna. Di Islam dilakukan dengan menapaki syariat, tareqat, hakekat, ma'rifat. Sejumlah Santo (sebagai contoh Santo Theresia) menyebutkan pada akhirnya yang tersisa hanya kerinduan untuk mencinta. Dirangkum menjadi satu, ada pergeseran dari kesalehan ritualistik (tunduk pada kebiasaan tua yang dogmatis), menuju kesalehan asketik (pengendalian diri) sehingga kemarahan, keserakahan lenyap diganti rasa lapar untuk menyayangi.

Dari penjelasan tersebut di atas, pemahaman tentang asketisme adalah latihanlatihan disiplin rohani penyangkalan diri untuk mendapatkan kemampuan dalam pengendalian diri, melatih kehendak, pikiran, dan jiwa untuk mencapai kehidupan rohani yang lebih tinggi. 


\section{Yoga dan Asketisme.}

Ajaran Yoga merupakan salah satu bagian dari ajara agama Hindu memberikan langkahlangkah dalam sadhana. Rsi Patanjali menyebut dengan delapan anggota tubuh (astangga ) yoga, yakni: Yama (Pantangan), Niyama (kebajikan pembantu), Asana (sikap-sikap tubuh dan meditasi), Pranayama (penguasaan nafas vital), Pratyahara (penyaluran aktivitas mental), Dharana (pemustan pikiran), Dhyana (meditasi/perenungan) dan Samãdhi (keadaan supra sadar transenden) (Mayor Polak, 1979: 45). Bagian pertama dari Astangga yoga diawali dengan Yama merupakan bagian etikanya yoga yang menuntun prilaku hidup harmonis dengan orang lain. Sebuah fondasi yang harus dibangun bagi seseorang yang mendirikan ajaran yoga dalam diri yang diawali dengan Yama dan dilanjutkan dengan Niyama. Sebagai sebuah etika terdapat ajaran yang memberikan aturan moral. Disiplin moral merupakan jurus yang ampuh mengatasi insting-insting destruktif ( Anata Gotama, 2000).

Asana dalam ajaran yoga bukan saja memberikan manfaat secara fisiologis, tetapi juga dapat memberikan pada kesehatan mental. Asana berarti" sikap tubuh yang enak dilakukan". Tekanan lembut dari sikap asana yang dilakukan dengan tenang dalam jangka waktu tertentu memperbaiki pengeluaran cairan hormon yang mengakibatkan keseimbangan hormon dan kesehatan fisik dan mental. Asana memberikan efek terhadap kelenjar-kelenjar endoktrin pada manusia. Dalam tubuh manusia terdapat kelenjar yang paling misterius yang disebut kelenjar pineal, yang terletak di tengahtengah otak. Para filsuf di jaman dulu menyadari akan pentingnya kelenjar kecil yang berbentuk jamur ini dan menyebutnya "inti jiwa" atau " pengendali pikiran (Avadhutika Anandamitra Acarya, 2001). Para yogi meyakini bahwa kelenjar ini merupakan jejak "mata ketiga" oleh para ilmuwan dikatakan sensitif terdapat pada mahluk hidup manusia. Sejak berabad-abad para yogi telah mengajarkan jika "intuisi mata ketiga " dikembangkan dengan baik dan "dibuka" dengan latihan-latihan yoga maka akan menghasilkan kebahagiaan suasana jiwa dan kesadaran intuitif yang halus. Riset yang dapat memperkuat konsep yoga, dengan ditemukannya bahwa kelenjar pineal mengeluarkan cairan hormon yang disebut "seratonim" dan "melatonim". Kelenjar ini bukan saja mempengaruhi organ-organ tubuh tetapi juga mempengaruhi situasi pikiran. Disebutkan bahwa kelenjar pineal sensitif terhadap cahaya, maka selama gelapnya malam makajumlah melatonim yang dikeluarkan sangat tinggi dan jumlah seratonim sangat rendah. Hal ini menghasilkan rasa rileks pada tubuh dan pikiran sehingga orang tersebut menjadi mudah tertidur. Sebaliknya sepanjang siang hari kadaan berlawanan terjadi yaitu jumlah melatonim berkurang dan jumlah seratonim bertambah sehingga menghasilkan suasana penuh aktivitas.

Kesimbangan pengaturan produksi seratonim secara bertahap akan maka seseorang merasakan keadaan semakin damai dalam memasuki kesadaran yang lebih tinggi dan dapat merasakan kebahagiaan bathin dan perasaan bersatu dengan alam. Para yogi mengembangkan latihan-latihan asana di antaranya adalah untuk memberikan efek pada kelenjar pineal sehingga memperoleh kesadaran mental yang lebih halus seperti gerakan asana yang disebut Shashaungasana (sikap tubuh seperti kelinci). Sikap Shashaungasana ini kepala menyentuh lantai dengan demikian akan memijat kelenjar pineal yang ada di otak. Oleh para yogi meyakini karena produksi melatonim bertambah dan seratonim berkurang maka sikap ini disebutkan dapat mengembangkan kesabaran dan ketenangan bathin.

Langkah -langkah ajaran yoga sebagai sadana akan mengantarkan pada asketisme spiritual yaitu latihan-latihan penyangkalan diri untuk mendapatkan kemampuan dalam pengendalian diri. Pengendalian diri merupakan bagian yang sangat penting dalam kehidupan manusia. Dengan pengendalian diri akan dapat 
mencegah munculnya perbuatan-perbuatan yang menyimpang dari kaedah-kaedah ajaran agama. Menurut Bhagawadgita manusia diyakini memiliki dua sifat kecendrungan yang terdapat dalam dirinya. Dua sifat itu membedakan kecendrunagn-kecendrungan disebut daivi sampad yaitu kecendrungan sifat kedewataan, dan asuri sampad yaitu kecendrungan sifat keraksasaan (Sura, 1985)

Ketika sifat keraksasaan mendominasi dalam diri manusia, ada kecendrungan akan muncul sifat insting-insting destruktif. Sebagai manusia yang memiliki Tri Premana ( $s a b d a$, bayu dan idep) sifat tersebut bukan saja membahyakan dirinya sendiri tetapi juga orang lain. Insting-insting destruktif merupakan pemikiran-pemikiran yang berdaya rusak tinggi seperti (himsãdayah), apakah ia diperbuat, disebabkan oleh atau disetujui, maupun dimotivasi oleh keserakahan (lobha), kemurkaan (krodha), ataupun kebingungan karena mabuk (moha). Demikian pula apakah yang kwalitasnya halus ( $m r d u)$, menengah (madhya), ataupun intens (adhi). Semua insting-insting destruktif tersebut mengakibatkan penderitaan dan semakin tebal dan berkepanjangannya kabut kebodohan. Dalam mengatasi insting-insting yang destruktif sifatnya vitarka, hadirkanlah sifat-sifat yang berlawanan dengannya (pratipaksa bhavana).

Dalam Patanjali Raja Yoga terdapat dua sutra yang dapat disebut sebagai prilaku asketis spiritual dilakukan untuk mengatasi insting destruktif tersebut yaitu dengan mengembangkan sifat-sifat yang berlawanan ( pratipaksa bhàwana) .

Witarkà bàadhane pratipaksa bhàwanam (YS II.33)

Terjemahannya:

Bilamana pikiran terganggu oleh pemikiran yang tidak layak hendaknya senantiasa mengusahakan pemikiran lawannya (Mayor Polak, 1979 : 290).
Witarkà himsàdayah krta kàritànumodità lobha krodha moha pùrwaka mrdhu madhyàdhimatrà duhkhà jnànànanta phala iti pratipaksa bhàwanam (YS II.34) .

Terjemahannya:

Sebagai pemikiran yang tidak layak, emosi (dan kegiatan-kegiatan ) semacam kekerasan dsb. Apakah itu dilakukan (untuk kesenangan diri) yang disebabkan oleh hasutan, apakah disebabkan oleh keserakahan, kemarahan atau kebingungan, apakah kehadirannya lembut, menengah atau intensif, menyebabkan kesedihan atau kebodohan berkepanjangan ; sehingga diperlukan untuk mengusahakan pemikiran lawannya (Mayor Polak, 1979 : 291).

Dalam dua sloka ini ditekankan pratipaksa bhàwana dengan metode mengembangkan sifat-sifat atau kecenderungan yang berlawanan dengan insting-insting distruktif itu sendiri. Metode ini dikembangkan atas fakta bahwa 'pikiran hanya dapat memegang satu objek saja, pada suatu saat yang sama'. Dengan metode berlawan ( dengan pikiran positif) maka bentuk-bentuk pemikiran destrutif tidak punya kesempatan untuk mengisi pikiran, bilamana pikiran telah terisi oleh pemikiranpemikiran konstruktif, yang menunjang pengembangan dan pemurniaan batin (cittasuddhi) (Anata Gotama, 2010). Dengan pengembangan metode tersebut berfungsi sebagai latihan rohani sehingga akan dapat menuntun dalam asketis spiritual.

Rsi Patanjali menekankan tentang ketiga tindakan pikiran negatif atau golongan anti etika sesuai intensitasnya. Suatu tindakan negatif yang berintensitas lemah yang disebut $m r d h u$ atau lembut, kesalahan yang berintensitas sedang (madhya) atau menengah, tindakan distruktif tinggi (adhimatra) atau berlebihan. Apabila seseorang tidak waspada maka tindakan pikiran negatif yang lemah sekalipun 
dapat menjadi sedang dan akhirnya bisa menjadi besar. Demikian juga sebaliknya bila mana seseorang berusaha dengan sungguh-sungguh, sadar, bertobat, sekalipun tindakan pikiran negatif yang besar dapat dihilangkan dengan menjadikan madhya terlebih dahulu.

\section{KESIMPULAN}

Prinsip-prinsip yang dianut oleh pratipaksa bhàwana adalah langkah asketisme spiritual sebagai latihan rohani dalam ajaran yoga. Agar secara instingtif tidak berharap muncul pemikiran-pemikiran yang bersifat himsa misalnya, maka hadirkan selalu yang berlawanan, yaitu dengan ahimsa, membangun semangat persaudaraan cinta kasih. Asatya atau ketidak benaran dengan menghadirkan Satya (kebenaran). Steya atau keserakahan dari pencurian dihadirkan dengan pratipaksa bhàwana Asteya, dan sebagainya. Sehingga ajaran yoga secara asketis akan memberikan kekuatan iman, dapat meningkatkan disiplin hidup baik mental, pikiran, badan dan jiwa serta kesejahteraan hidup.

\section{DAFTAR PUSTAKA}

Amin Abdullah, Prof. DR. HM. Amin Abdullah ; 2011, ( Idul Fitri dan Asketisme Sosial )

Anatta Gottama, 2010. Yoga Sutra (alih bahasa) Denpasar : tp.

Cudamani, 1987. Pengantar Agama Hindu . Jakarta : Yayasan Wisma Karma

Cudamani, 1999. Mengatasi Stres Menurut Pandangan Hindu. Surabaya: Paramita.

Polak, Mayor. J.B.A.F, Patanjali Raja Yoga, Surabaya : Paramita

Prama, Gede, 2010. Pencerahan dalam Perjalanan, Jakarta : PT Gramedia Pustaka Utama.

Prama, Gede, 2013. Compassion, Jakarta : Karaniya

Sura, I Gede, 1985, Pengendalian Diri dan Etika Dalam Ajaran Agama Hindu, Jakarta: Hanuman Sakti.

Viani Leave, March 20, 2013 Viani Leave a comment

Max Weber, 2012, Sosiologi Agama $a$ Handbook, Jogyakarta: IRCiSoD 